\title{
Implementasi Model Waterfall Pada Sistem Informasi Pengiriman Barang Berbasis Web
}

\author{
Susafa'ati \\ Sekolah Tinggi Manajemen Informatika dan Komputer Nusa Mandiri \\ e-mail: susafa.suf@bsi.ac.id
}

\begin{abstract}
Shipping goods systems is still done manually, from serving customers until data storage which related to shipping process of making a report, so errors in registration, less accurate and delay report of required data is occurs. information system design is the best solution to solve the existing of shipping goods, as well as with the computerized system which is effective and efficient to support activities on the Web shipping item.
\end{abstract}

Keywords: shipping goods system, Web.

\section{PENDAHULUAN}

Saat ini, kemajuan teknologi semakin meningkat dan dengan adanya penemuan-penemuan baru dibidang teknologi menimbulkan banyaknya perubahan di segala bidang. Salah satu kemajuan teknologi tersebut dengan komputer. Komputer selain membuat pekerjaan yang di kerjakan oleh manusia lebih praktis, cepat dan mudah. Komputer juga dapat dihubungkan dengan internet, sehingga dapat diakses oleh masyarakat.

Perusahaan cabang yang bergerak dibidang expedisi jasa pengiriman barang merupakan sebuah perusahaan yang melayani beberapa jasa yaitu salah satunya adalah dibidang jasa ekspedisi pengiriman barang ke berbagai tempat antar daerah.

Kendala yang dihadapi perusahaan cabang ini adalah pembuatan laporan pengiriman dan penerimaan barang masih menggunakan alat tulis biasa. Dalam melakukan proses pengiriman barang, pelanggan juga harus datang langsung ke perusahaan dan melakukan transaksi secara langsung. Selain itu, pelanggan tidak dapat memantau keberadaan barang. Oleh karna itu, terciptalah keinginan untuk membuat sistem informasi online berbasis web yang diharapkan memudahkan pelanggan untuk mengetahui informasi dan pelanggan dapat memantau secara langsung keberadaan barang yang sedang dikirim.

Maksud dibangun nya aplikasi sistem informasi pengiriman barang ini adalah :

1. Pengelola data yang dilakukan secara terkomputerisasi memungkinkan terhindar dari kesalahan pemasukan data.

2. Mengembangkan sistem pick-up order sehingga memungkinkan pemesanan secara online untuk menjemput barang yang akan dikirim.
Saat ini perkembangan sistem informasi yang berbasis web banyak digunakan sebagai sarana peningkatan informasi hampir di semua bidang usaha, baik bidang perdagangan, industri maupun pendidikan. Penggunaan sistem informasi berbasis web dapat menjadi sarana promosi yang efisien (Susafaati, 2016).

Terminal kargo adalah salah satu fasilitas pokok pelayanan di dalam bandar udara yang bertujuan untuk kelancaran proses kargo, bagi yang keluar maupun ke dalam dan memenuhi persyaratan keamanan dan keselamatan penerbangan (Musyafir,2011).

Jasa (Service) adalah aktivitas atau manfaat yang ditawarkan oleh suatu pihak kepada pihak lain yang pada dasarnya tanpa wujud dan tidak menghasilkan kepemilikan apapun (Silahaan, 2011)

\section{Model Waterfall (Air Terjun)}

Menurut Limaye (2009) "Model waterfall adalah model pengembangan perangkat lunak yang paling sederhana dan digunakan secara luas dalam penelitian proses pembangunan".

Tampilan model waterfall sebagai berikut :

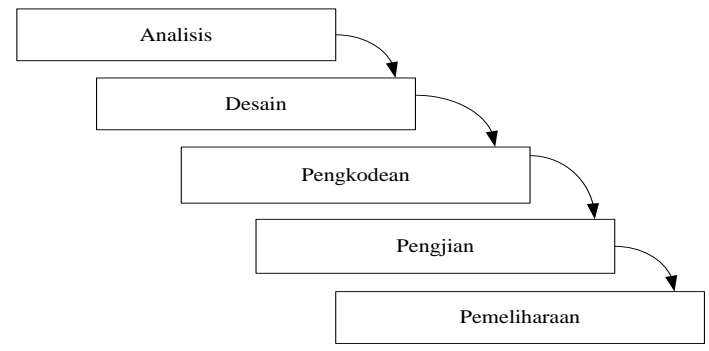

Sumber : Limaye (2009)

Gambar 1 Model Waterfall 
Keterangan menurut gambar diatas alur dari Model Waterfall sebagai berikut :

a. Analysis (Analisis)

Proses pengumpulan kebutuhan diintensifkan dan difokuskan, khususnya pada perangkat lunak. Untuk memahami sifat program yang dibangun, rekayasa perangkat lunak (analisis) harus memahami domain informasi, tingkah laku, unjuk kerja dan antar muka (interface) yang diperlukan.

b. Design (Desain)

Desain perangkat lunak sebenarnya adalah proses multi langka yang berfokus pada empat atribut sebuah program yang berbeda. Struktur data, arsitektur perangkat lunak, representasi interface dan detail (algoritma) procedural.

c.Coding (Pengkodean)

Pengkodean yang mengimplementasikan hasil desain kedalam kode atau bahasa yang dimengerti oleh mesin computer dengan menggunakan bahasa pemrograman tertentu.

d. Testing (Pengujian)

Kegiatan untuk melakukan pengetesan program yang sudah dibuat apakah sudah benar atau belum di uji dengan cara manual. Proses pengujian dilakukan pada logika internal untuk memastikan semua pernyataan yang sudah diuji. Pengujian eksternal fungsional untuk menemukan kesalahankesalahan dan memastikan bahwa input akan memberikan hasil yang actual sesuai yang dibutuhkan.

e. Pemeliharaan

Perangkat lunak yang sudah disampaikan kepada user pasti akan mengalami perubahan. Perubahan tersebut bisa karena mengalami kesalahan karena perangkat lunak harus menyesuaikan dengan lingkungan (peripheral atau sistem operasi baru), atau karena user membutuhkan perkembangan fungsional atau unjuk kerja.

\section{METODOLOGI PENELITIAN}

Untuk menunjang kelancaran penulisan ini, ada beberapa metode pengumpulan data yang digunakan. Adapun metode-metode pengumpulan data yang digunakan adalah :

\section{A. Metode pengembangan Perangkat Lunak}

Model Waterfall adalah model klasik yang bersifat sistematis, berurutan dalam membangun software. Berikut ini ada dua gambaran dari waterfall model (Pressman.S. Roger. PH.D, Andi, 2012).

Fase-fase dalam model waterfall menurut Pressman:

\section{Communication}

Langkah ini merupakan analisis terhadap kebutuhan software, dan tahap untuk mengadakan pengumpulan data dengan melakukan pertemuan dengan customer, maupun mengumpulkan data-data tambahan baik yang ada di jurnal, artikel, maupun dari internet.

2. Planning

Proses planning merupakan lanjutan dari proses Communication (analysis requirement). Tahapan ini akan menghasilkan dokumen user requirement atau bisa dikatakan sebagai data yang berhubungan dengan keinginan user dalam pembuatan software, termasuk rencana yang akan dilakukan.

3. Modeling

Proses modeling ini akan menerjemahkan syarat kebutuhan ke sebuah perancangan software yang dapat diperkirakan sebelum dibuat coding. Proses ini berfokus pada rancangan struktur data, arsitektur software, representasi interface, dan detail (algoritma) prosedural. Tahapan ini akan menghasilkan dokumen yang disebut software requirement.

4. Construction

Construction ini merupakan proses membuat kode. Coding atau pengkodean merupakan penerjemah desain dalam bahasa yang bisa dikenali oleh komputer. Programmer akan menerjemahkan transaksi yang diminta oleh user. Tahapan inilah yang merupakan tahapan secara nyata dalam mengerjakan suatu software, artinya penggunaan komputer akan dimaksimalkan dalam tahapan ini. Setelah pengkodean selesai maka akan dilakukan testing terhadap sistem yang telah dibuat tadi. Tujuan testing adalah menemukan kesalahan-kesalahan terhadap sistem tersebut untuk kemudian bisa diperbaiki.

5. Deployment

Tahapan ini bisa dikatakan final dalam pembuatan sebuah software atau sistem. Setelah melakukan analisis, desain dan pengkodean maka sistem yang sudah jadi akan digunakan oleh user. Kemudian software yang telah dibuat harus dilakukan pemeliharaan secara berkala.

\section{B. Teknik Pengumpulan Data}

1. Observasi

Observasi adalah pengumpulan data dengan cara mengunjungi aplikasi.

2. Studi pustaka

Mengumpulkan data melalui buku-buku, situs internet, dan catatan kuliah yang erat kaitannya dengan tema dari tugas akhir. 


\section{HASIL DAN PEMBAHASAN}

\section{A. Analisis Kebutuhan}

Analisis Kebutuhan merupakan fungsi-fungsi yang harus dimiliki sistem yang dibutuhkan oleh user sistem.

1.

\section{Administrator}

a) Admin dapat melihat, menambah, mengedit dan menghapus data barang.

b) Admin dapat melihat dan menghapus data testimonial.

c) Admin dapat melihat dan menyetujui data transaksi.

d) Admin dapat melihat, mengedit dan menghapus data pengguna.

2. User

a) User dapat melihat berbagai informasi pengiriman yang tersedia.

b) User dapat melakukan pendaftaran sebagai mamber dan login.

c) User dapat melihat about us.

d) User dapat melakukan transaksi pengiriman barang setelah menjadi mamber.

e) User dapat melihat dan memberikan testimonial setelah menjadi mamber.

\section{B. Perancangan Perangkat Lunak}

1. Rancangan Antar Muka

a. Rancangan Antar Muka Halaman Login

Admin

Halaman login admin dirancang untuk masuk kedalam ruang admin, dan sebagai proteksi halaman admin dari para pengguna yang tidak bertanggung jawab. Rancangan antar muka halaman admin adalah sebagai berikut :

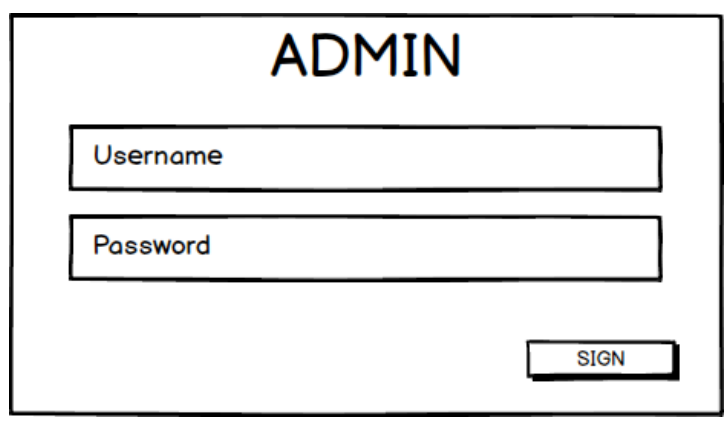

\section{Gambar 2. Rancangan Antar Muka Beranda Admin}

b. Rancangan Antar Muka Halaman Biaya kirim Halaman ongkos kirim adalah halaman yang dibuat untuk admin dapat menghapus, menambah dan mengedit biaya ongkos kirim. Rancangan antar muka halaman ongkos kirim adalah sebagai berikut :

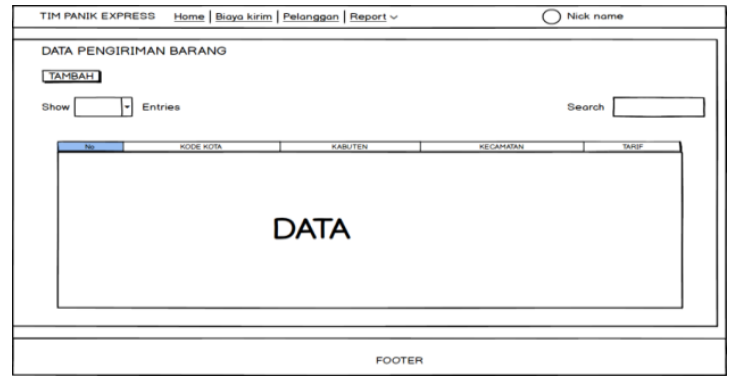

\section{Gambar 3. Rancangan Antar Muka Biaya Kirim}

c. Rancangan Antar Muka Halaman Pelanggan

Halaman pelanggan adalah halaman yang dibuat untuk admin. Dapat menghapus, menambah dan mengedit pelanggan. Rancangan antar muka halaman pelanggan adalah sebagai berikut :

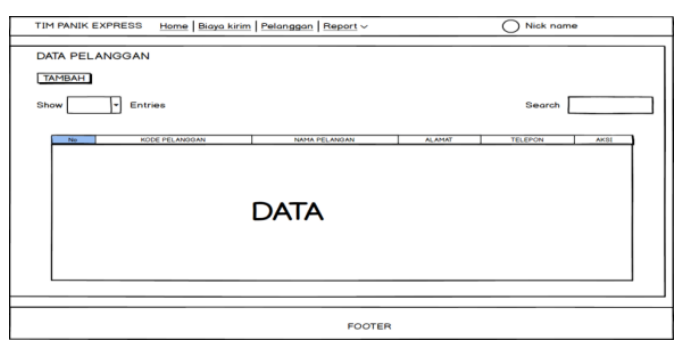

Gambar 4. Rancangan Antar Muka Halaman Pelanggan

d. Rancangan Antar Muka Halaman Transaksi

Halaman transaksi adalah halaman yang dibuat untuk admin melihat apakah ada atau tidak transaksi agar admin dapat mengelola transaksi pengiriman. Rancangan antar muka halaman transaksi adalah sebagai berikut :

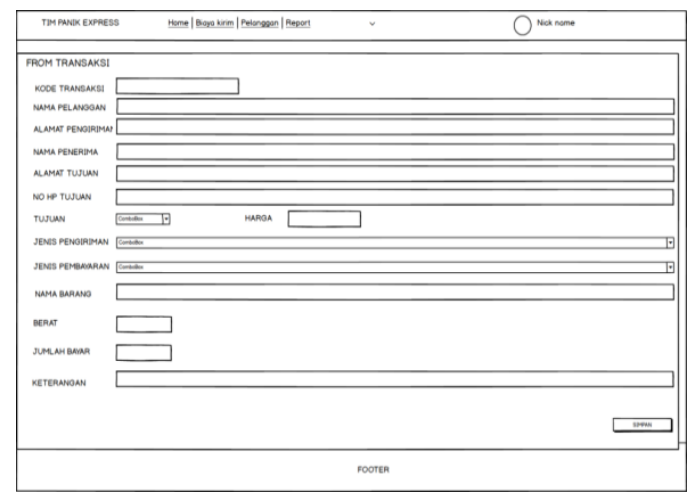

Gambar 5. Rancangan Antar Muka Halaman Transaksi

e. Rancangan Antar Muka Halaman Laporan

Halaman laporan adalah halaman yang dirancang untuk admin dapat melihat laporan transaksi dan mencetaknya. Rancangan antar muka 
laporan transaksi adalah sebagai berikut :

\begin{tabular}{|c|c|c|c|c|c|}
\hline \multicolumn{6}{|c|}{ LAPORAN PENGIRIMAN } \\
\hline KOOE PEVIGIRNAN & NAMAPEVIGRMAN & NAAMAPE & AMAT TUVU & N KEANARN & TIAGGGL KRIM \\
\hline 88000004 & Mdeos Fojer Di Nivgoto & gildodig & stitodf & Ampenon & $207 \cdot 0 \cdot 1 \cdot 17$ \\
\hline 88000003 & Mdeos Fojer Dw Nuggoto & gildodiog & solodf & Ampenon & $207.07 \cdot 15$ \\
\hline 88000001 & Mdees Four Dw Nuggoto & lalibodig & solodit & Ampenon & $2077.07 \cdot 16$ \\
\hline
\end{tabular}

Gambar 6. Rancangan Antar Muka Halaman Laporan

f. Rancangan Antar Muka Halaman Tambah Admin

Halaman Tambah admin adalah halaman yang dirancang untuk admin dapat menambahkan data admin dan menghapusnya. Rancangan antar muka tambah admin adalah sebagai berikut :

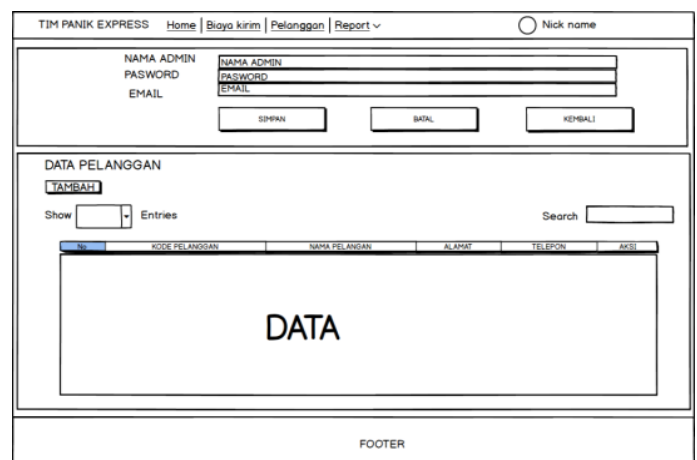

Gamabar 7. Rancangan Antar Muka Halaman Tambah Admin

g. Rancangan Antar Muka Halaman Tracking User

Halaman Tracking User adalah halaman yang dirancang untuk user dapat melihat alur perjalanan pada barang yang di kirim. Rancangan antar muka tracking user adalah sebagai berikut :

\begin{tabular}{|c|c|c|c|c|}
\hline \multicolumn{5}{|c|}{ TIM PANIK EXPRESS Home | Torit| Trooking } \\
\hline & \multicolumn{2}{|c|}{ Masuken id Trocking } & \multicolumn{2}{|l|}{ Cori } \\
\hline Tanggal & Kode Pengiriman & Nama Barang & Posisi & Tujuan \\
\hline & & & & \\
\hline & & & & \\
\hline & & & & \\
\hline & & FOOTER & & \\
\hline
\end{tabular}

Gamabar 8. Rancangan Antar Muka Halaman Tracking User
C. Entity Relationship Diagram (ERD)
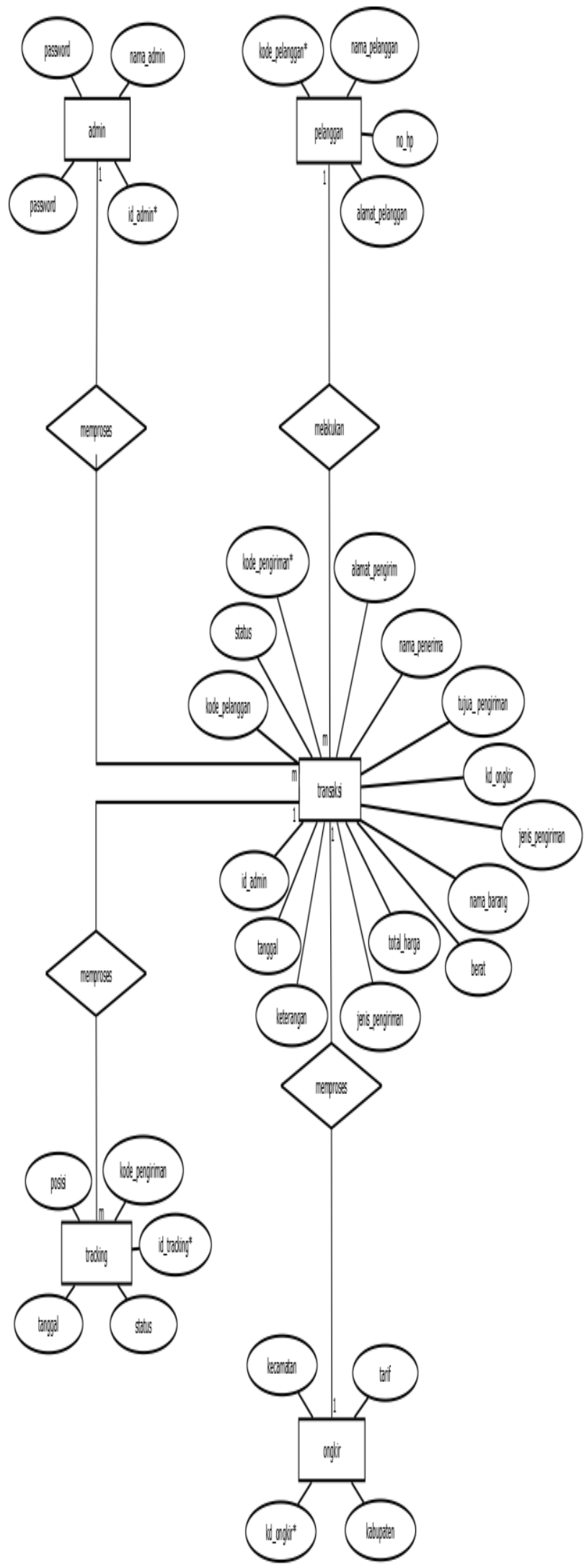

Gamabar 9. Entity Relationship Diagram (ERD) 


\section{Implementasi}

a. Antar Muka Home User

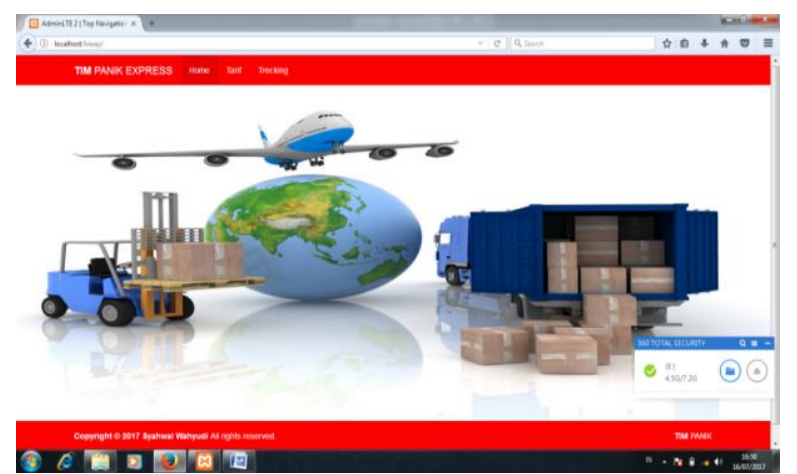

Gamabar 10. Tampilan Halaman Home Pengunjung

b. Antar Muka Biaya Pengiriman Barang

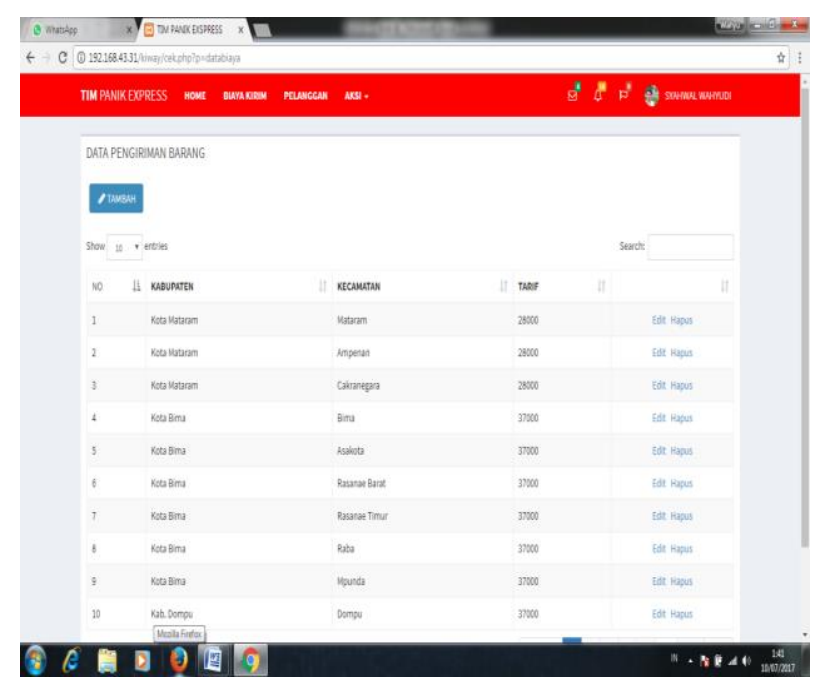

Gamabar 11. Tampilan Biaya Pengiriman Barang

c. Antar Muka Biaya Kirim

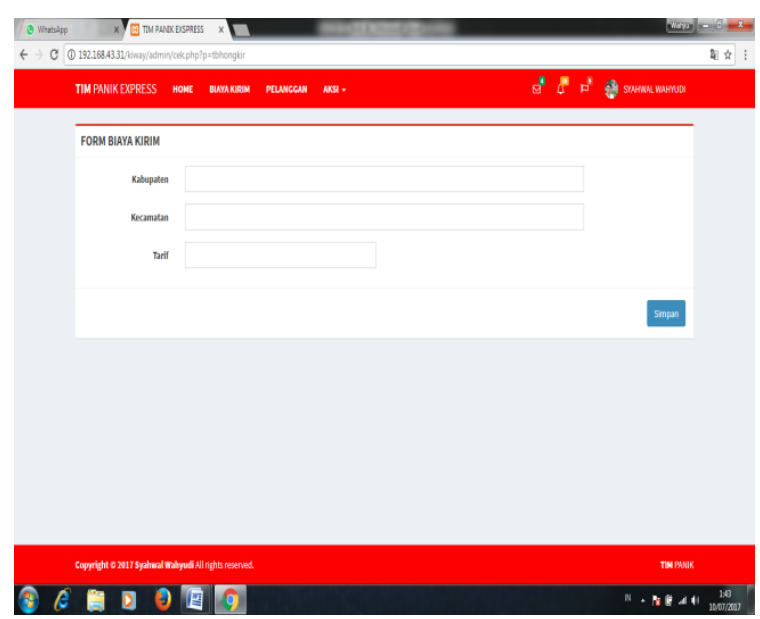

Gamabar 12. Tampilan Biaya Kirim d. Antar Muka Data Pelanggan

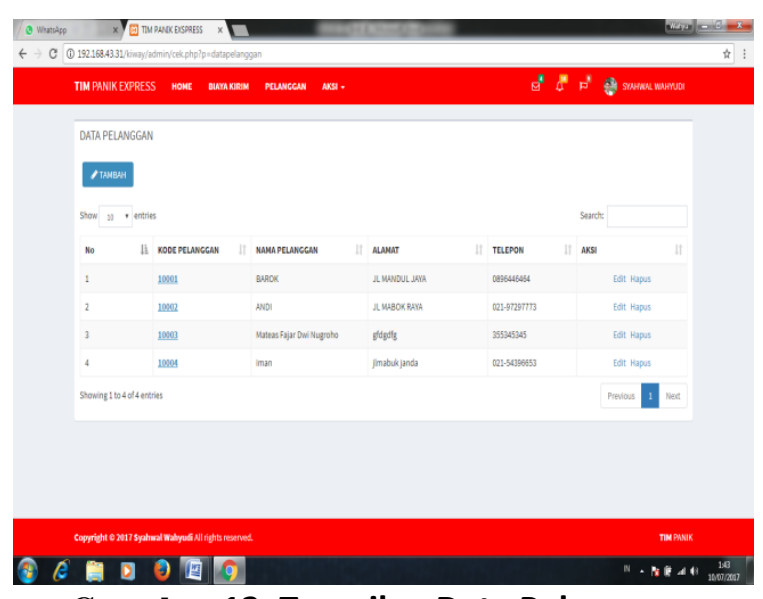

Gamabar 13. Tampilan Data Pelanggan

e.Tampilan Antar Muka From Pelanggan

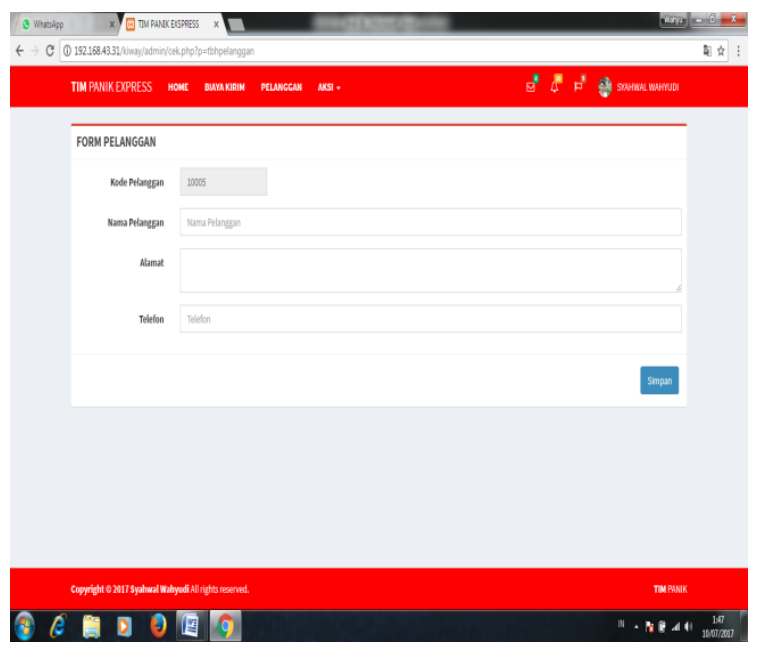

Gamabar 14. Tampilan Form Pelanggan

f. Tampilan Antar Muka From Transaksi

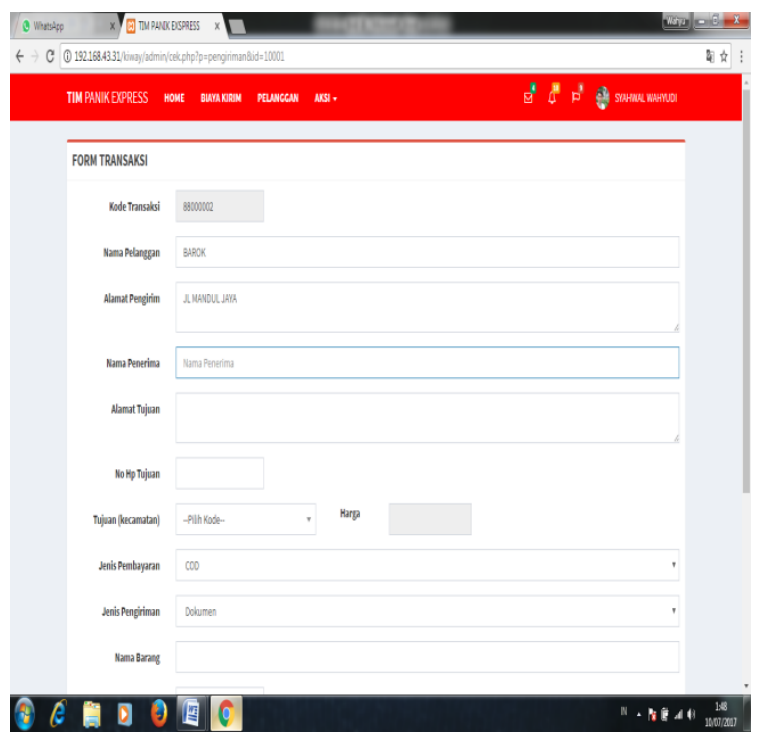

Gamabar 15. Tampilan Form Transaksi 


\section{g. Tampilan Antar Muka Data Pengiriman Barang}

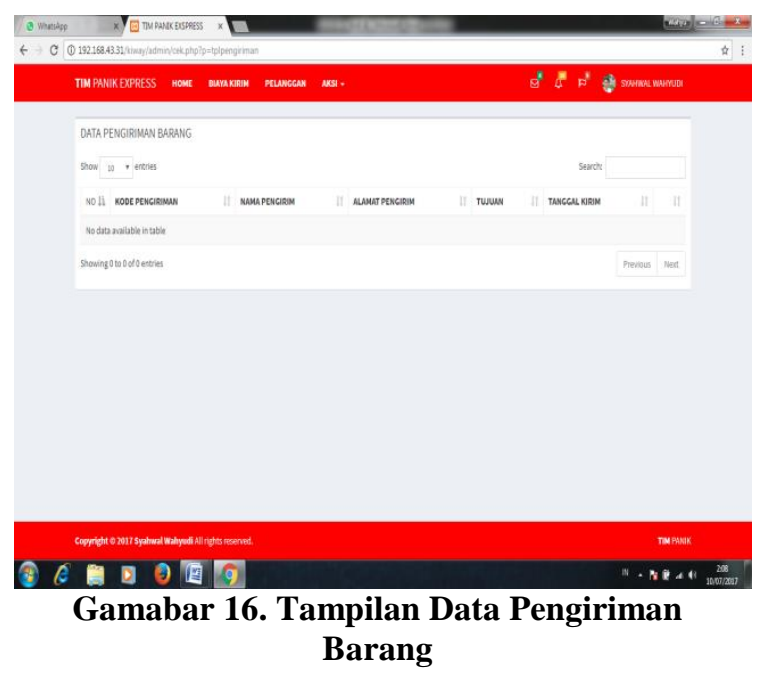

h. Tampilan Antar Muka From biaya kirim

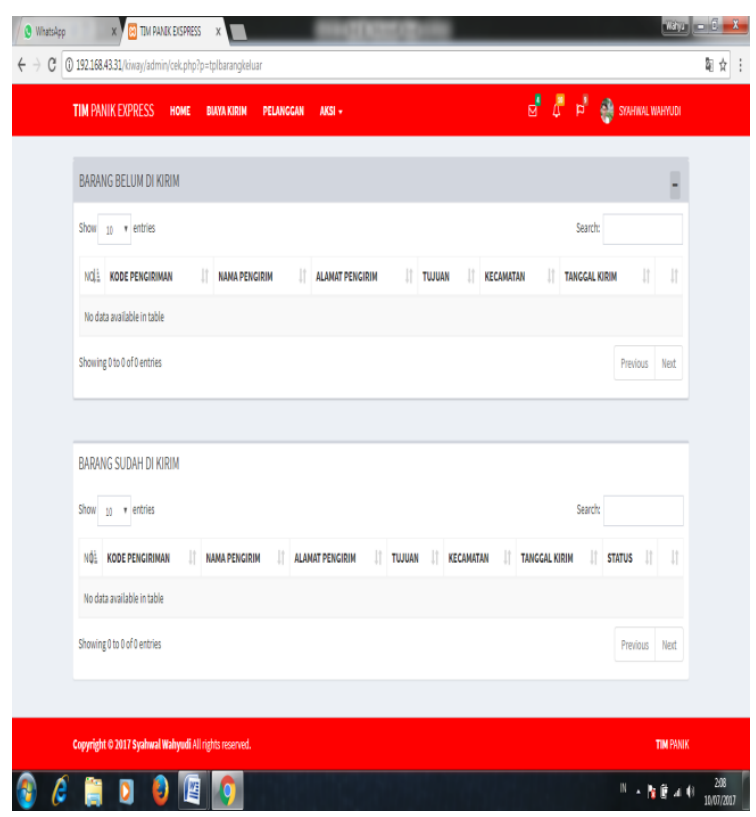

Gamabar 17. Tampilan Form Biaya Kirim

\section{KESIMPULAN}

Setelah menjalankan sistem aplikasi pengiriman barang ini dapat disimpulkan antara lain sebagai berikut :

1. Mempermudah proses pengiriman barang dan meringankan karyawan untuk menginput data pelanggan untuk bertransaksi

2. Menghasilkan informasi dalam bentuk web serta dilakukan dengan cepat, tepat dan akurat.

3. Tingkat pelayanan terhadap konsumen atau pelanggan menjadi jauh lebih baik dan lebih cepat.

4. Kemudahan dalam pencarian data layanan, data kota tujuan, data tarif, data pengiriman dan data penerima.

\section{REFERENSI}

Susafaati, 2016, Pelayanan Cargo Udara Berbasis Online pada Jasa Pengiriman Barang (Studi Kasus Pada PT. Lancar Semesta Dirgantara), Jurnal Techno Nusa Mandiri Vol. XIII, No. 2 September 2016

Musyafir, 2011, Studi Evaluasi Kinerja Terminal Cargo Bandar Udara Hasanuddin. ISSN. 1411-7797. Vol. 12, No. 41

Siahaan, Juanda, 2011, Layanan Kargo Udara Internasional dibandara Udara Soekarno Hatta.

Limaye. 2009. Software Testing. New Delhi: Tata Mc Graw Hill Education Private Limited.

Pressman.S. Roger. PH.D, Andi 2012.Rekayasa Perangkat Lunak-Pendekatan Praktisi. Yogyakarta:Andi.

\section{PROFIL PENULIS}

Susafa'ati, M.Kom, Lahir di Jepara, 30 Januari 1988. Setelah lulus SMEA langsung Melanjutkan Studi ke Diploma III (D3) dengan Program Studi yang diambil Manajemen Informatika (MI) di AMIK BSI Jakarta dan lulus Tahun 2010, Setelah Lulus D3 Melanjutkan kuliah ke Program Sarjana (S1) dengan Program Studi Sistem Informasi dari STMIK Nusa Mandiri Jakarta dan Lulus tahun 2012. Melanjutkan Kuliah Program Pasca Sarjana (S2) dengan Program Studi Ilmu Komputer di STMIK Nusa Mandiri Jakarta dan Lulus Tahun 2014. Saat ini Menjadi Pengajar (Dosen) pada STMIK Nusa Mandiri. Email: susafa.suf@bsi.ac.id Jurnal dan publikasi ilmiah:

a. Susafaati, 2015, Pengukutan Kepuasan Penggunaan Aplikasi LSD Air Freight Cargo dengan Metode UTAUT, Jurnal PILAR Nusa Mandiri Vol XI, No.2 September 2015

b. Susafaati. 2016, Pelayanan Cargo Udara Berbasis Online Pada Jasa Pengiriman Barang (Studi Kasus Pada PT. Lancar Semesta Dirgantara, Jurnal TECHNO Nusa Mandiri, Vol. XIII No.2. September 2016

c. Deni Gunawan, Dwi Puji Hastuti, Ria Andriani, Susafaati, 2018, Sistem Informasi Penjualan Berbasis Web Pada Restoran Caki Cake Karawang, Jurnal AKRAB JUARA Volume 3 Nomor 1 Edisi Februari 2018 (116)

d. Isma Santi Arini, Susafaati, 2017, Perancangan Sistem Informasi Penjualan Sepeda Motor Pada PT. Formula Diptajati Jakarta, Jurnal INTERKOM Vol 12. No. 3 - Oktober 2017 